\title{
A STUDY VARIOUS FACTORS RELATED TO SUICIDE PROBABILITY
}

\author{
H. Tuğcu*
}

\section{ABSTRACT}

In this study, the relation of various personal, social and family characteristics to suicide probability levels of depressive patients and normal's are evaluated.

Another aim is, one is to adapt Suicide Probability Scale (SPS) to Turkish culture which could be used for assessment and prediction of suicidal behavior. Results showed that several factors indicate significantly high suicide probability scores. These factors are; family history of attempted suicide, trouble with the spouse and low social skills level.

Key Words: Suicide probability, Depression, Suicide Probability Scale (SPS)

\section{Çeşitli Faktörlere Göre İntihar Olgusu Çalışması}

\section{ÖZET}

Bu çalışmada, normal ve depresif hastalarda bireysel, ailesel ve sosyal özellikler gözden

* Dr. Psk., Ankara Üniversitesi, Tıp Fakültesi, Psikiyatri Anabilim Dalı. geçirilerek, intihar olasılığı düzeyleri değerlendirilmiştir.

Ayrıca, İntihar Olasılığı Ölçeği, Türk Kültürüne uyarlanarak intihar davranışının belirleyicileri değerlendirilmiştir. Bulgularda, bazı faktörlerin anlamlı derecede yüksek intihar olasılığı skoru verdiği görülmüştür. Bu faktörler, ailede intihar girişimi öyküsü, eşle yaşanan sorunlar, düşük sosyal beceri düzeyi olarak belirlenmiş̧ir.

Anahtar Kelimeler: İntihar olasılığı, depresyon, İntihar Olasılığı Ölçeği (ioÖ)

\section{INTRODUCTION}

In the last few decades increase of suicide and suicide attempts has been a great problem in many countries. This increase is influenced by social, economical and cultural changes. Turkey is one of the countries which have a low suicide rate according to data of national suicide statistics (DIE 2003). Over the past 20 years there is a rapid social change and technological development due to industrial and modernization process in the country. Negative effects of these changes are experienced mostly by people living in big cities. 
Up to the year 1989 trends of suicide in Turkey was consistent but showed a gradual increase after this year. Especially a remarkable increase was observed in the year 2001.

On the other hand suicide attempts it was found that rates of suicide attempts also increased (Özgüven \& Sayıl 2003). Morever there is a considerable amont of studies in clinical and research literature which points out the professional interest in the assessment and management of suicidal behavior (Sayıl \& Uçan 2005).

The present study has had two aims; One is to adapt the Suicide Probability Scale (SPS) to Turkish culture which could be used for assessment and prediction of suicidal behavior. The other one is the identification of particular risk factors in suicide.

\section{METHOD}

Sample: The sample consisted of 100 depressed patients and 100 control subject. Age range of the sample were 15-65 years of age and the mean of age was 38.1. Depressed cases were chosen from 2 psychiatric hospitals of Ankara and were diagnosed by using DSM-III criteria. Besides the Turkish version of Beck Depression Scale was used for identifiying depresive cases and who hand total scores over the cut off score wich is 22 were included to the sample (Scores over the cut-off point=22).

The normal group was included in the sample if they didn't receive a psychiatric treatment currently or in the past. The two groups (depressed-control) were similar to each other in terms of age, gender and level of education.

\section{INSTRUMENT}

1. Personal Information Questionnaire: It has developed by the first outhor to assess the sociodemographic, psychological, social and familial charcteristic of suicide attempters. In the pilot study of the questionnaire item were pre- pared based on the retrospective data of the suicide attempters who admitted to the psychiatry clinics and to crisis intervention center of Ankara University from these records 33 factors were determined and the suggestions of clinicians working in this field were asked. The final form was prepared towards the suggestions of the professionals having experience in the field of suicide prevention.

2. Suicide Probability Scale: The original SPS is a 36 item, self report measure that assesses suicide risk in adults and adolescents. Individuals are asked to rate the frequency of their subjective experience and past behaviors using a 4-point Likert scale ranging from "None" to "all of the time". The SPS also provides four clinical subscales: Hopelessness (12 items), Suicide Ideation (8), Negative Self-Evaluation (9) and Hostility (7). An overall assessment of suicide risk is reflected in three summary scores. These are a total weighted score, a normalized $T$ score, and a suicide probability score which can be easily calculated. High scores of the scale reflects the high suicide probability. SPS is a highly reliable and valid instrument (Cull, Wayne 1988; Zachary, Raid et al. 1982).

In the present study SPS was translated to Turkish by mental health professionals and back translation was made by two teachers performing English teaching. Internal consistency of the Turkish version of SPS was calculated for the whole as well as for the subscales. The optained Alpha coeficients in the normal group for the whole scale was .85 and ranged between $.74-.49$ for the subscales. Test-retest reliability coefficients for the total scale $(r=.98)$ as well as for the subscales: Hopelessness (.84), Negative Self Evaluation (.42), Suicide Ideation (.70) and Hostility (.70) were calculated in a 4 week interval.

Construct validity were examined by coparing the total mean scores and the mean subscale scores of the SPS of depressive and normal groups by using "t" test. The SPS total 
mean score as well as the mean subscale scores of the depressed group were higher than the normal group. In the depressive group mean SPS scores for the scale as a whole was $=77.95$ and was $=26.88$ for hopelessness, $=20.04$ for suicide Ideation, =16.43 for Negative Self Evaluation and $=14.51$ between the two groups were found to be statistically significant

$$
\left(\mathrm{t}_{\text {Total }}=3.28, \mathrm{t}_{\mathrm{Hop}}=8.76, \mathrm{t}_{\mathrm{NSE}}=6.22, \mathrm{t}_{\mathrm{HOS}}\right.
$$
$=6.56, p<0.001)$.

On the other hand depressed cases having a suicide attempt in the past had the highest and statistically significant scores with respect to non-suicidal depressed cases $\left(t_{T}=3.06\right.$, $\mathrm{p}<0.005$ ).

The concurrent validity of SPS was examined by using Turkish version of "Beck Hopelessness Scale-BHS" as a criterion (Seber et al 1993; Durak, Palabıyıkoğlu 1994). The correlation coefficients between the two scales was .84 for the total scale and for Hopelessness, Suicide Ideation, Negative Self Evaluation, Hostility Scales was .81, .68, .5 and .66 repsectively (Tuğcu 1996).

\section{RESULTS}

In order to investigate the risk factors in suicidal behavior Turkish version of SPS was administered to normal and depressed groups. To evaluate the significance of the group differences on the SPS scores ANOVA procedure was utilized for each risk factor. Results of the variance analysis showed that there were signifant differences on SPS scores between the two groups. Within the groups significant main effect was found on SPS scores concerning some risk factors, such as; emotional stability $(\mathrm{F} 2,194=6.56, \quad \mathrm{p}<.001)$, expression of anger $(F 3,192=5.70, p<.01)$, experiencing stresful life events (F1.196=9,36, $p<.03)$, having a physial disease $(F 1,196=5.29, p<.02)$ caring of an ill family member ( $F 1,196=6.39, p<.01)$, number of close friends $(F 3,192=9.41, p<001)$, and past suicide attempt $(F 1,196=4.74, p<.03)$.
When the $F$ scores was found significant Turkey test was performed in order to find the source of differences. Moreover, due to the results of variance analyses, main effect and interaction effect was found significant on the SPS scores related to the variables given below: perception of low social skills level ( $F 2,194=13.12, p<.001),(F 2,194=2.95, p<.04)$, relation with the spouse $(F 1,194=3.30, p<.04)$, $(F 1,194=3.91, p<.02)$ and suicide attempted family member $(F 1,196=11.07, \quad p<.001$, $\mathrm{F} 1,196=6.97, \mathrm{p}<.01)$. within both groups who perceived their social skills as inadequate had the highest mean SPS score $(=77,69)$ compared to groups who perceived as sufficient $(=62,41)$ or mediocre $(=69,76)$. This result indicates the importance of perceived social skills in suicide probability. Anova results also revealed to SPS scores caried due to the suicidal member within the family of both groups.

SPS mean scores of normal $(=70,67)$ and depressive groups $(=80,38)$ having a suicide attempted individuals in their family was higfher than non-suicidal members within the family environment. The normal group without a suicidal family member has the lowest mean SPS score $(=52.28)$ compared to non-suicidal members in families of the depressed group $(=77,49)$. Family history of attempted suicide is another significant risk factor with respect to suicide probability either in clinical or in normal groups.

In the results variance analysis, significant main effect $(F 1,194=3.30, p<.04)$ and interaction effect $(F 1,194=3.91, p<.02)$ was found on SPS total scores related to satisfactory relations with the partner. Perception of unsatisfactory relations with the spouse resulted in high mean SPS scores in depressed as well as in normals compared to satisfactory relations with the spouse. This findings indicate the high suicide probability in married individuals who experience conflicts with their spouse. 


\section{DISCUSSION}

In the present study various factors related to suicidal behavior were investigated by using Turkish version of SPS which the psychometric properties were examined. According to the results it was found that SPS as a whore is a reliable and valid instrument for Turkish culture, but one subscale of SPS (Negative SelfEvaluation) have not sufficient reliability and validity coeffecients. The psychometric properties of this subscale must be analyzed again using different groups in other studies.

In the second part of the study predictors of suicide were assessed as difficulties in social relations generally and communication problems in the family especially with the partner. These results are consistent with the findings of the studies in literature (Aydın 1990; Aysev 1992; Ceyhun 1992; Dilsiz\&Dilsiz 1993; Palabıyıkoğlu 1992; 1993; Sayıl, Azizoğlu 1992). Another important finding of the study was having a suicidal person in the family. This result indicates the learning and modeling aspects of suicidal behavior and is consistent with the literature findings that stresses the high suicide probability in these individuals (Garfinkel Golombek 1974; Hawton 1987; Martin, Koomarek, Gertridge 1987; Moscicki 1995).

The results of this study revealed thet there is a need for social skills training and community based educational programs for coping with stressful events in Turkish population. On the other hand the importance of marriage counseling must be stressed in the society. 


\section{REFERENCES}

Aydın H (1990) The Psychosocial Characterestics and Prevention of Suicidal Behaviour. XXXII. International Congrees of Military Medicine and Pharmacy, Madrid.

Aysev A (1992) İntihar Girişimi Olan Çocuklarda Yaşam Olayları. Kriz dergisi 1(1), 17-21.

Ceyhun B, Ergin G, Durukan A (1992) Life Stres: In The Predisposition of Suicidal BehaviorCrisis, Special Issue, 32-34.

Cull JG, Gill WS (1988) Suicide Probability Scale Manual Western Psychological Services, Los Angeles, California.

DiE (2003) Suicide Statistics. State Institute, of Statistics Prime Ministry Republic of Turkey. Ankara.

Dilsiz A, Dilsiz F (1993) İntihar Girişimlerinde Belirtilen Nedenler, Kriz Dergisi, 1(1):124-128.

Durak A, Palabıyıkoğlu R (1994) Beck Umutsuzluk Ölçeğinin Geçerlik Çalışması. Kriz Dergisi 2(2): 311-319.

Garfinkel BD, Golombek (1974) Suicide and Depression in Childhood and Adolescence. Canadian Medical Association Journal, 110: 1287-1281.

Hawton K (1987) Assessment of Suicide Risk British Journal of Psychiatry. 150: 45-153.

Martin D, Kocmarek I, Gertridge S (1990) A Handbook fort the Caregiver on Suicide Prevention. The Board of Education for the City of Hamilton, Canada.

Moscicki EK (1995) Epidemiology of Suicidal Behavior. Suicide and Life Threatening Behavior. 25: 22-23.
Özgüven HD, Sayıl I (2003) Suicide Attempts in Turkey: Results of the WHO-EURO Multicentre Study on Suicidal Behaviour. Can J Psychiatry, 48: 324-329.

Palabıyıkoğlu R (1992) Krize Müdahale Kriz Merkezi Çalışanlarının Bir Yıllık Değerlendirmesi. Kriz Dergisi 1(1): 13-17.

Palabıyıkoğlu R, Azizoğlu S, Özayar H, Berksun O (1993) İntihar Girişimi Olan ve Olmayan Depresiflerin Aile İşlevselliği. Kriz Dergisi, 1(3): 114123.

Sayıl I, Oral A, Güney S, Ayhan N, Ayhan Ö, Devrimci H (1993) Ankara'da İntihar Girişimleri Üzerine Bir Çalışma. Kriz Dergisi, 2(2): 293-298.

Sayıl I (1994) Türkiye'de İntihar Sorunu. Kriz Dergisi, 2(2): 293-298.

Sayıl I (2000) Intiharlar. Ruh Sağlığı ve Hastalıkları. (Ed: Sayıl I, Özgüven HD) Antıp A.Ş. Yayınları. s: 203-214, Ankara.

Seber G, Dilbaz N, Kaptanoğlu C, Tekin D (1993) Umutsuzluk Ölçeği: Geçerlik ve Güvenirlik. Kriz Dergisi; 1(3), 139-142.

Tuğcu H (1996) Normal ve Depresif Kişilerde Çeşitli Faktörlere Göre İntihar Olasılığı. Hacettepe Üniversitesi Sosyal Bilimler Enstitüsü Doktora Tezi, Ankara.

Uçan Ö (2005) Türkiye'de İntiharı Konu Alan Yayınlar Üzerine Bir Bibliyografya Çalışması. Kriz Dergisi; 13(3), 15-26. 